\title{
THE RISE IN YOUTH EMPLOYMENT? IMPACT EVALUATION OF COVID-19 CONSEQUENCES
}

\author{
Lucia Svabova \\ University of Zilina, Slovakia \\ Barbora Gabrikova \\ University of Zilina, Slovakia
}

\begin{abstract}
The COVID-19 pandemic has significant consequences in many areas and has largely contributed to rising unemployment in almost all countries. The situation is similar in Slovavkia, where various degrees of shutdown measures have caused an inflow of newly unemployed people in all age groups. This article focuses on unemployed youth as a vulnerable and disadvantaged group of the working population, as starting a career during a pandemic is complicated or even impossible in some industries under these conditions. In this study, the real situation in Slovakia in 2020-2021 is compared with the development of the job market before the pandemic and its counterfactual prediction under the hypothetical situation of no pandemic. The main contribution of the study is the quantification of the extent of the pandemic impact on unemployed youth, but also on other age groups; this evaluation can be considered very accurate given the counterfactual approach used. The analysis uses a counterfactual before-after comparison together with a statistical model for predicting the development of the inflow of the number of newly unemployed, which provides an accurate quantification of the amount of the pandemic's impact on unemployment. The results of this study can be used in practice to identify the most affected groups of the population and to implement policy measures aimed at mitigating the effects of the pandemic, and then to adjust the intensity and amount of allocated funds that will be needed to be spent to support the placement of young people into the labor market.
\end{abstract}

Keywords: COVID-19 consequences, Impact evaluation, Jobseekers, Youth Unemployment

DOI: http://dx.doi.org/10.15549/jeecar.v8i4.757

\section{INTRODUCTION}

After the coronavirus disease - COVID-19 - was first detected in Wuhan, China in December 2019 , no one could have predicted the impact it woiuld have on our society. Although the human race has dealt with various diseases in the past, such as the Spanish flu or the Zika virus, COVID19 has become memorable. The virus causing this disease spread relatively quickly $\mathrm{f}(\mathrm{McGann}$ et al., 2020) from Wuhan to the whole world. Thanks to globalization, the transmission of the virus to other continents was a matter of a few days or weeks (Dvorak et al., 2020). Many 
countries took various restrictive measures to reduce the spread of the virus immediately in the first quarter of 2020, however, their adoption had an immediately negative impact not only on the global economy but also on the economies of individual countries (Ibn-Mohammed et al., 2021). Employers were forced to lay off employees in an effort to avoid bankruptcy (Galea \& Abdalla, 2020; Marinescu et al., 2021; McGann et al., 2020), thus increasing a population's unemployment rate in different age groups (Graham \& Ozbilgin, 2021; Svabova et al., 2020). The situation was the same in the Slovak Republic. In March 2020, the government adopted strict anti-pandemic measures such as closing borders, schools, shopping centers, hotels, churches, the complete abolition and prohibition of mass events, or restrictions on production in large companies (Nemec, 2020).

Young people are often described as a group of the population less at risk from COVID-19 in terms of health, but the possible economic impact of this pandemic on young people needs to be considered. According to Organization for Economic Cooperation and Development (OECD) statistics, the unemployment rate for US youth in the first quarter of 2020 was $9 \%$ for men and 8.5 $\%$ for women, but after the outbreak of the pandemic, it rose sharply in the second quarter, rising to 22.87 \% for men and 25.73 \% for women. A similar situation was observed in the labor market in Canada. In contrast, in the European Union countries, the increase in the youth unemployment rate was more moderate, with an average unemployment rate of $15.07 \%$ for young men and $14.8 \%$ for women (OECD, 2020b, 2021). Although there was an increase for both genders in the second quarter, the youth unemployment rate rose to $16.37 \%$ for men and $17.13 \%$ for women (ILO-OECD, 2020; OECD, 2020b). The same situation was observed in Slovakia, where youth unemployment increased between the first and second quarters of 2020. The unemployment rate for men rose from $15.20 \%$ to $19.60 \%$ and for women from $18.47 \%$ in the first quarter to $21.17 \%$ in the second quarter. Therefore, unemployment rates for both genders were higher than the unemployment rate for young men and women in the European Union (OECD, 2020b, 2020a).
We assume that the pandemic, but mainly government measures against it, impacted unemployment, even in a group of young people. Therefore, this study is focused on young people, analyzing the development of their unemployment rate using the variable inflow of newly registered unemployed youth. Furthermore, their situation is compared to the impact of the pandemic on unemployment in other age groups. Since young people are not much discussed as a threatened group, we see the main gap that we are trying to fill in with this study. Therefore, we analyze the development of the indicator mentioned above for youth unemployment, where the main contribution of this study is the use of real data on youth unemployment in Slovakia from 2013 - 2020. Furthermore, we approach the analysis in a counterfactual way, where the use of the beforeafter comparison method allows us to quantify the real impact of the pandemic on youth unemployment. Given the set of real data used and the application of the counterfactual approach, we consider this study to be innovative in this field.

The rest of the paper is organized as follows. First, the literature review section highlights recent studies addressing the same or similar issues. Then, the methodology and data section describes the data used in this study and briefly describes the principle of the counterfactual evaluation approach applied in this study. Next, the results section provides the quantification of the impact of the pandemic on a group of young people in Slovakia. In the discussion, the results of the study are compared with similar studies of other authors. The last section concludes and mentions the main weaknesses of the study and its possible future direction.

\section{LITERATURE REVIEW}

As Song and Zhou (2020) stated in their study, to slow the spread of the virus, various kinds and degrees of shut-down restrictions were adopted, especially in the world's major economies. As a result, the economic activities of production, trade, transport, and services slowed down or even stopped, leading to a significant reduction in economic activity and a rise in unemployment. As a result, the COVID-19 pandemic triggered a substantial global crisis and caused an increase in 
unemployment in all layers of the population, but the impact of the pandemic on unemployment varies from country to country (Blustein et al., 2020; Milani, 2021). Ismayilzade et al. (2021) stated that it should be the centerpiece of efforts to ensure rapid and sustainable recovery of the national economy's curent conditions.

Currently, when the pandemic is still a hot topic, several authors are examining its impact on youth unemployment in individual countries or sectors. A study by Churchill (2021) examined the impact of the pandemic on youth employment in Australia, in terms of gender, compared to the older generation. Based on Australian Bureau of Statistics data, research has shown that young people have also been significantly affected by the pandemic regarding their unemployment compared to the older generation. The economic impact and the government's response to the pandemic put young people at a significant disadvantage (O'Keeffe et al., 2021). Ranchhod and Daniels (2021) analyzed the labor market dynamics in South Africa at the beginning of the pandemic. Research has revealed that women and young people are among the most affected groups. Djoumessi (2021) examined the impact of the COVID-19 pandemic in Cameroon, where the the employment situation of companies was significantly affected by the pandemic in various sectors. To avoid bankruptcy, companies have been forced to reduce working hours, lay off employees or reduce wages. Almeida and Santos (2020) examined in their study the effects of the pandemic on the labor market in Portugal. They found that the impact of the pandemic on the labor market was asymmetric, mainly differing based on regions, sectors, or age groups. Tourist regions are the most affected, while young people and women with unstable employment are perceived as the most affected groups. The impact of the pandemic on the labor market in Romania was analyzed in the study by Radulescu et al. (2021), where the impact was probably most reflected on the most vulnerable sections of the active population, such as women, young people, and workers with lower wages and poor working conditions. The situation in the Canadian labor market is addressed in a study by Lemieux et al. (2020), where the authors examined the impact of a pandemic on the labor market at the time of the outbreak from February to April 2020. Al-Youbi et al. (2020) examined the effects of the pandemic on the labor market in Saudi Arabia. In their study, the authors underlined the important position of universities, which can integrate the changing conditions of the labor market into their curricula and thus educate graduates who are currently needed on the market, thereby helping to restore the domestic labor market. In the study. Von Wachter (2020) discussed the possible impact of the COVID-19 pandemic on unemployment in the US labor market. The article focused on vulnerable people, such as people who have lost their jobs and those entering the labor market for the first time as recent graduates.

The issue of unemployment in the Slovak Republic is addressed in the study of Svabova et al. (2020), where the authors focused on the analysis of unemployment in 2020, examining the overall unemployment rate and developments in the various sectors of economic activities. Some authors dealt with the problem of unemployment in Slovakia even before the pandemic. Greganova and Pietrikova (2017), in their study, examined unemployment in individual regions of Slovakia. Danielova and Lauko (2014) analyzed the impact of the economic crisis on the differences in wages between men and women and the development of unemployment. Labor market conditions and emigration trends in Slovakia and neighboring EU countries were examined by Privara (2020). Fialova and Mysikova (2021) addressed the employment of young people in the Visegrad Group countries (Czech Republic, Hungary, Poland, Slovakia), where they examined the impact of minimum wages on employment and regional differences. The situation of young people in the labor market in the countries of the Visegrad Group is also addresses by Kopacek and Horackova (2018). Flek et al. (2018) examined unemployment in countries such as the Czech Republic, Poland, and Slovakia in terms of age groups.

\section{METHODOLOGY AND DATA}

According to the ILO-OECD (2020), OECD (2020a) and (OECD 2020b, the youth unemployment rate is defined as the number of 
unemployed aged $15-24$, expressed as a percentage of the youth workforce. Therefore, in this study, we focused on young people under the age of 25 and the development of their unemployment from April 2020 to April 2021 in the context of the COVID-19 pandemic in Slovakia. In March 2020, the first cases of the virus appeared in Slovakia, and the government introduced strict measures which came into force immediately. It was, among other things, a restriction or complete closure of almost all shops, restaurants, or similar facilities, sports facilities and the like. In addition, the production and operation of several production companies were affected by the restrictions in force abroad. The situation was reflected in April 2020 by the inflow of new unemployed into the register of jobseekers. This database of jobseekers is maintained by the Center for Labour, Social Affairs and Family of Slovakia (COLSAF) through local labour offices. COLSAF publishes on its website data on jobseekers monthly, publishing the numbers of unemployed and their detailed categorization by gender, level of education, region of permanent residence, age, disadvantages, and economic activity of the last employer. Special attention is also paid to women, for whom all the above data are published. We compiled a database from such monthly data in the form of a time series of data on jobseekers from January 2013 to April 2021. We focused on the unemployed in terms of age, with the following age groups: Up to 25 years (in the sense of 24.99 years), from 25 to 55 (up to 54.99 ) years, and 55 years and over. We are interested in the inflow of new unemployed who registered in the database of jobseekers in a given month. In the study, we focused mainly on the impact of the COVID-19 pandemic on youth unemployment, but we also followed the other two age groups to compare the quantity of the impact on youth unemployment with other age groups.

Let $D$ be the treatment indicator variable; in this study, it is the pandemic, where $D=1$ means the situation under the pandemic and $D=$ 0 marks the situation without the pandemic (Dvoulety \& Lukes, 2016; Stefanik, 2014; Stefanik et al., 2020). Let $Y$ mark the result variable; in this study, it is the inflow of newly unemployed. Thus, the impact evaluation aims to compare the values of the result variables in case $D=1$, with the values in case $D=0$ (Frondel \& Schmidt, 2005; Kruppe \& Lang, 2018). Let $Y_{t}$ be the result variables in a period $t$ (Liu \& Wang, 2020) and, more precisely, $Y_{t 0}$ is a value of the result variable in a situation without a pandemic $Y_{t 0}=Y_{t} \mid D=0$, and $Y_{t 1}$ in a situation under the pandemic $Y_{t 1}=$ $Y_{t} \mid D=1$. Then, the causal effect of the pandemic could be directly quantified as the difference of the values of the result variable $Y_{t 1}-Y_{t 0}$, or in general, without time-subscript as $Y_{1}-Y_{0}$ (Trivellato, 2011).

Here the problem of immeasurability of the data arises, however. In fact, in time $t$ we cannot measure the value of the result variable in the case of the pandemic and also in the case without the pandemic. As a result, we are not able to calculate the impact precisely by the difference in the result variable $Y_{1}-Y_{0}$. Instead, we estimate the expected value of this difference so that the impact of the pandemic is given by the Average Treatment Effect (Potluka et al., 2016).

$$
T E=E\left(Y_{1}\right)-E\left(Y_{0}\right)=E(Y \mid D=1)-E(Y \mid D=0) .
$$

Thus, the total average impact of the pandemic is estimated by the difference in the averages of the result variables in the situation $D=1$ and the counterfactual situation $D=0$ (Pelucha et al., 2019; Potluka et al., 2016). But the main problem with the immeasurability of the data remains, as in reality, that only one situation can occur: either the pandemic in time $t$ has occurred or it has not. Thus, of the two result variables $Y_{0}$ and $Y_{1}$ only one is always measurable. The situation without the pandemic is only hypothetical (Svabova \& Kramarova, 2021). Thus, the data on the values of the result variables $E\left(Y_{0 t}\right)=$ $E\left(Y_{t} \mid D=0\right)$, or simply $E\left(Y_{0}\right)=E(Y \mid D=0)$ cannot be measured because such data do not exist (Stefanik, 2014) and cannot be obtained by more measurements or detailed data. This problem is called the "fundamental problem of evaluation" or "fundamental problem of causal inference" (Trivellato, 2011). The expected value $E\left(Y_{0}\right)=E(Y \mid D=0)$ is thus counterfactual and expresses what would have happened on average if the pandemic had not occurred. This hypothetical counterfactual value of the result variable $Y_{0}$ could be estimated by various methods. In this study, given the nature of the available data, we applied one of the most common impact evaluation methods, the before- 
after comparison. The basic idea of this method is to create an acceptable counterfactual situation by comparing the situation "after" the pandemic with the situation "before" the pandemic. Or more precisely, the development of the situation before the pandemic with the real situation.

We first analyzed the time series of data on the inflow of new unemployed youth using its additive decomposition and characteristics calculation. Subsequently, we modeled the development of the trend of this series, shortening it to March 2020 (pre-pandemic period). In this model, we included the seasonal component as an explanatory variable. Youth unemployment also has a seasonal character, because in the months of graduation from high school or university, there is a higher inflow of newly unemployed, and the number of habitats in the given age group, which, of course, also affects the number of unemployed and changes over time. We then used the created model to evaluate the impacts of a pandemic using a counterfactual approach using the before-after comparison method. First, we created a hypothetical counterfactual situation to predict the further development of the inflow of new young unemployed for the period from April 2020 based on the created regression model. Then, we compared this prediction with the actual development of the number of newly unemployed in the period from April 2020. The resulting difference represented the impact of the pandemic on youth unemployment.

In counterfactual impact assessments, it is essential to exclude the influence of other factors that could also affect the values of the result variable (in this study, the inflow of new unemployed youth). If we did not use them as explanatory variables in the trend model of the result variable, the impact assessment results could be skewed. The results would be overestimated (or underestimated), and the impact of a given unmeasured variable on the result variable would be incorrectly attributed to the effect of the intervention (in this study, the pandemic). This problem is called an identification condition (Frondel \& Schmidt, 2005).

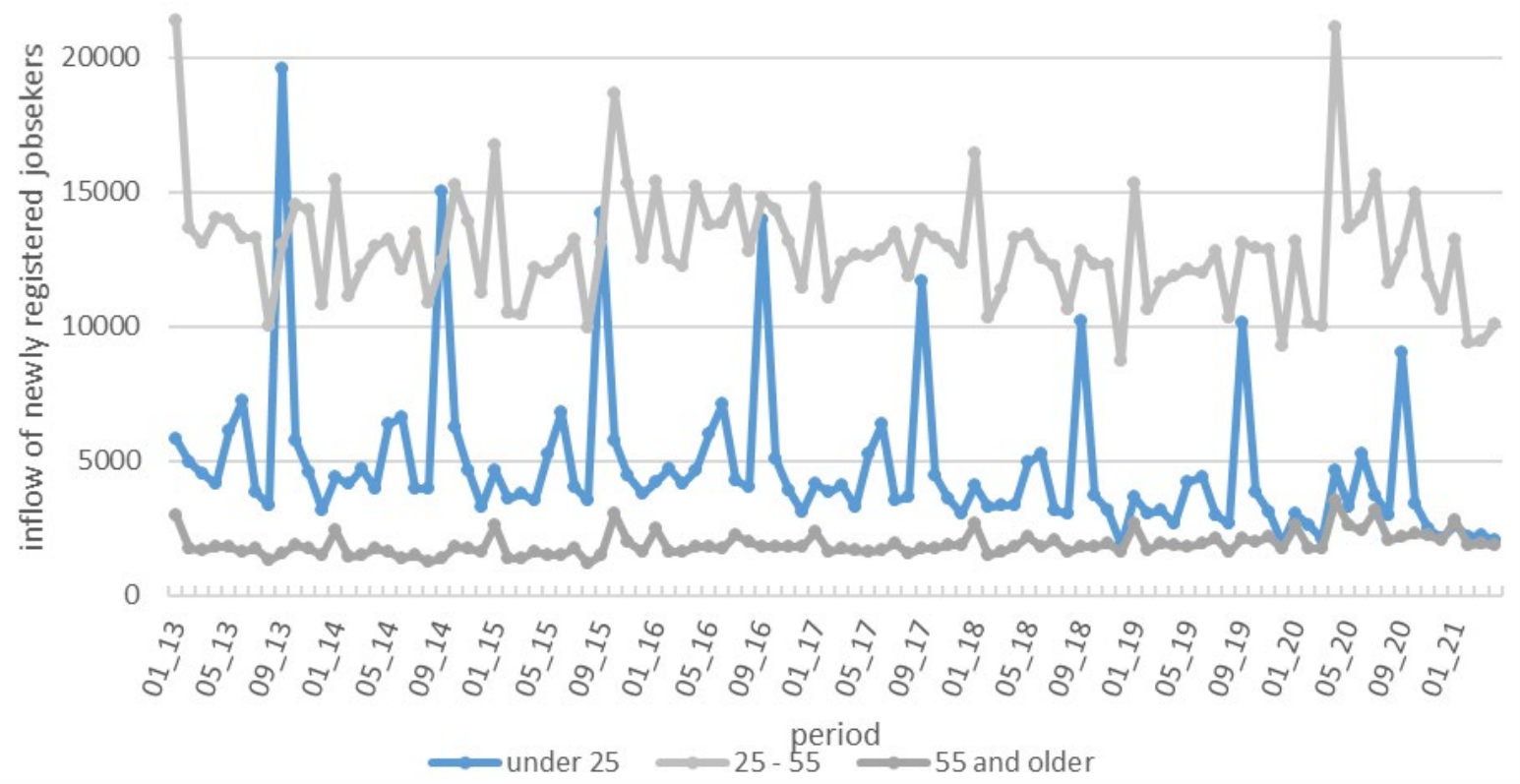

Figure 1: Monthly inflow of newly registered unemployed youth.

Source: own elaboration.

However, in this study we tried to avoid and eliminate this problem by using a long time series of monthly data, where we believe that in previous years, the effects of, for example, intervention policies aimed at the unemployed young, the situation in the labor market, or 
higher education, etc., have also manifested themselves. During 2020 and 2021, we considered the situation in Slovakia relatively stable; the impact of external intervention or a significant change in the situation (except the pandemic) is unknown, which could be an immeasurable variable and affect the results of the evaluation. We therefore consider the evaluation results to be sufficiently accurate.
Figure 1 shows the development of the result variable inflow of newly registered jobseekers during the period under the study. The blue graph shows the inflow of unemployed youth and the other two grey graphs are the numbers of new jobseekers aged 25 - 55 and over 55 for comparison.
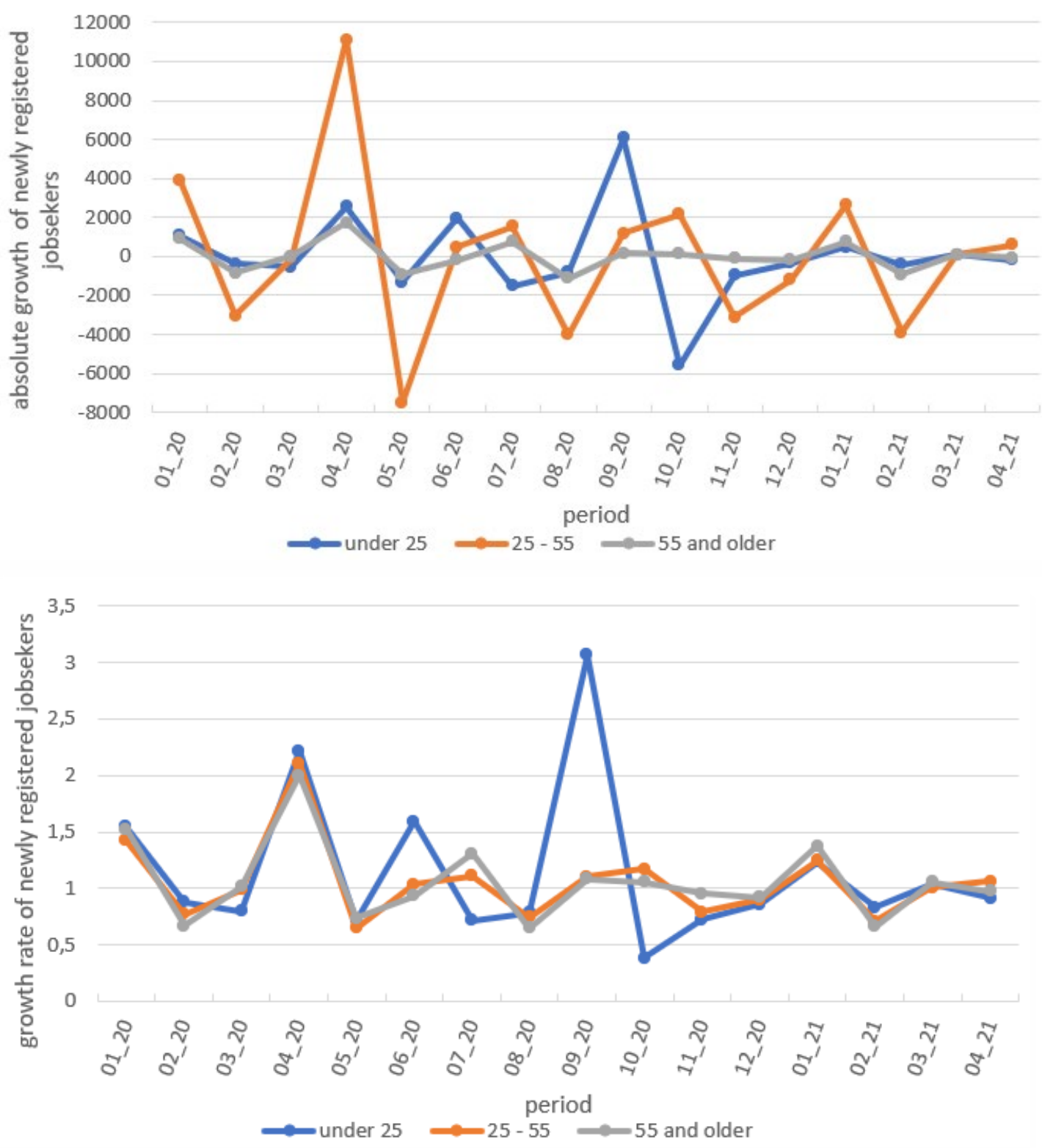

Figure 2: Monthly inflow of newly registered unemployed youth.

Source: own elaboration. 
In the inflow of newly registered youth jobseekers, it is evident that this time series contains a seasonal component. The cimpnent reflects the high number of newly registered unemployed young every September, which the inflow of new school graduates can explain. In Slovakia, high school graduates are entitled to holidays and do not have to register as jobseekers until the end of August. Therefore, every year in September, there is a high inflow of new youth jobseekers who are graduates of secondary schools in a given year. However, it is also visible that the seasonal component decreases over time, along with a slightly decreasing trend in the number of new young jobseekers. Therefore, we chose a multiplicative decomposition of this time series.

The number of jobseekers in the age group over 55 is relatively low throughout the whole period under study, but a closer look shows an increase in these numbers during 2020. In the age group of $25-55$, the number of unemployed individuals is much higher throughout the whole period than in the other two categories, and the increase in their number during 2020 is evident.
A closer look at the period since the beginning of 2020 is provided in Figure 2, where the left part shows the absolute monthly increase in the number of jobseekers and the right part presents the monthly growth rate.

In April 2020, when the anti-pandemic measures came into force in Slovakia for the first time, an increase in the absolute growth and growth rate can be seen. These results, however, may still be skewed in the light of developments in recent years and seasonal fluctuations, for example, such as the visible increase in the number of newly registered young jobseekers in September 2020. Therefore, more accurate results can be obtained by applying a counterfactual impact evaluation approach.

Table 1 indicates the numerical characteristics of the inflow of newly registered youth jobseekers. We present the characteristics for the whole period under the analysis, from January 2013 to April 2021, but also for the pre-pandemic period shortened to March 2020 and especially for the pandemic period of April 2020 - April 2021.

Table 1: Characteristics of the inflow of newly registered youth jobseekers

\begin{tabular}{|l|l|l|l|}
\hline Inflow youth & Whole period & Pre-pandemic period & Pandemic period \\
\hline $\mathbf{N}$ & 100.00 & 87.00 & 13.00 \\
\hline Mean & 4743.74 & 4923.56 & 3540.31 \\
\hline Std. Deviation & 2852.51 & 2932.69 & 1920.18 \\
\hline Variance & 8136805.20 & 8600676.57 & 3687085.23 \\
\hline Coeff of Variation & 60.13 & 59.56 & 54.24 \\
\hline Minimum & 1878.00 & 1878.00 & 2055.00 \\
\hline Maximum & 19559.00 & 19559.00 & 9013.00 \\
\hline Percentile 25 & 3251.50 & 3325.00 & 2214.00 \\
\hline Percentile 50 & 4000.50 & 4093.00 & 2940.00 \\
\hline Percentile 75 & 5047.75 & 5231.00 & 4189.00 \\
\hline
\end{tabular}

Source: own elaboration

According to these characteristics, the average number of young unemployed in the pandemic period appears lower than during the prepandemic period, but with high variability.
However, we will get more accurate results with a rigorous approach to counterfactual impact assessment. 


\section{RESULTS}

We focused on the time series of development of newly registered jobseekers, while we were mainly interested in young people, but we also presented the other two age groups for comparison. First, we modelled the time series of pre-pandemic data using a regression model. In this model, we used the number of inhabitants in a given age category as explanatory variables, which is published on a semi-annual basis
(Statistical office of the Slovak Republic, 2021) and months of the year in the form of dummy variables that describe the seasonality in the time series. The regression model was created for the period January 2013 - March 2020, which was a period without the pandemic. Using the stepwise method, we obtained the following regression model for the inflow of newly registered young jobseekers.

Table 2: Regression model of the inflow of newly registered youth jobseekers

\begin{tabular}{|l|c|c|c|c|c|c|c|}
\hline \multicolumn{1}{|c|}{ Variable } & $\begin{array}{c}\text { Unstandardized } \\
\text { Coefficients B }\end{array}$ & Std. Error & $\begin{array}{c}\text { Standardized } \\
\text { Coefficients } \\
\text { Beta }\end{array}$ & $\mathbf{t}$ & Sig. & $\begin{array}{c}\text { Collinearity } \\
\text { Tolerance }\end{array}$ & VIF \\
\hline Constant & -6459.31 & 1248.06 & & -5.18 & $<0.05$ & & \\
\hline $\begin{array}{l}\text { youth_- } \\
\text { population }\end{array}$ & 0.017 & 0.002 & 0.26 & 8.24 & $<0.05$ & 0.99 & 1.01 \\
\hline season=5 & 1522.67 & 346.53 & 0.14 & 4.39 & $<0.05$ & 0.96 & 1.05 \\
\hline season=6 & 2326.67 & 346.53 & 0.22 & 6.71 & $<0.05$ & 0.96 & 1.05 \\
\hline season=9 & 9788.98 & 346.12 & 0.91 & 28.28 & $<0.05$ & 0.96 & 1.04 \\
\hline season=10 & 1229.98 & 346.12 & 0.11 & 3.55 & $<0.05$ & 0.96 & 1.04 \\
\hline season=12 & -866.73 & 346.12 & -0.08 & -2.50 & 0.014 & 0.96 & 1.04 \\
\hline
\end{tabular}

Source: own elaboration

The months of May, June, September, October and December remained as significant variables in the regression model, expressing the seasonal nature of the inflow of new jobseekers. The model is statistically significant (ANOVA p-value $<0.05$ ) and describes almost $96 \%$ of the variability of the dependent variable $(\mathrm{R}$-square $=$ 0.959 , Adjusted R-square $=0.92$ ).

Using the created model, we can predict the values of the result variable $Y$ at the time of the pandemic, i. e. $Y_{1}$. These values represent the hypothetical counterfactual situation without the pandemic, from which we estimated the expected mean of the number of new young unemployed during the period April 2020 - April 2021

$E\left(Y_{1}\right)=E(Y \mid D=1) \doteq 3,747$.

We estimated the mean value of the real situation $Y_{0}$ using the actual values of the development of the inflow of newly registered young jobseekers during the period April 2020 April 2021.

$E\left(Y_{0}\right)=E(Y \mid D=0) \doteq 3,540$.

The average impact of a pandemic, estimated using the evaluation parameter $A T E$, given by (1), is therefore

$A T E_{\text {youth }}=E\left(Y_{1}\right)-E\left(Y_{0}\right)=3,747-3,540 \doteq 207$.

This means that, considering the seasonal nature of the inflow of newly unemployed people and the number of people at a given young age, the pandemic had an impact on increasing the number of new young jobseekers by 200 people per month. Detailed numbers of the actual and estimated number of inflows of new youth jobseekers are shown in Figure 3. 


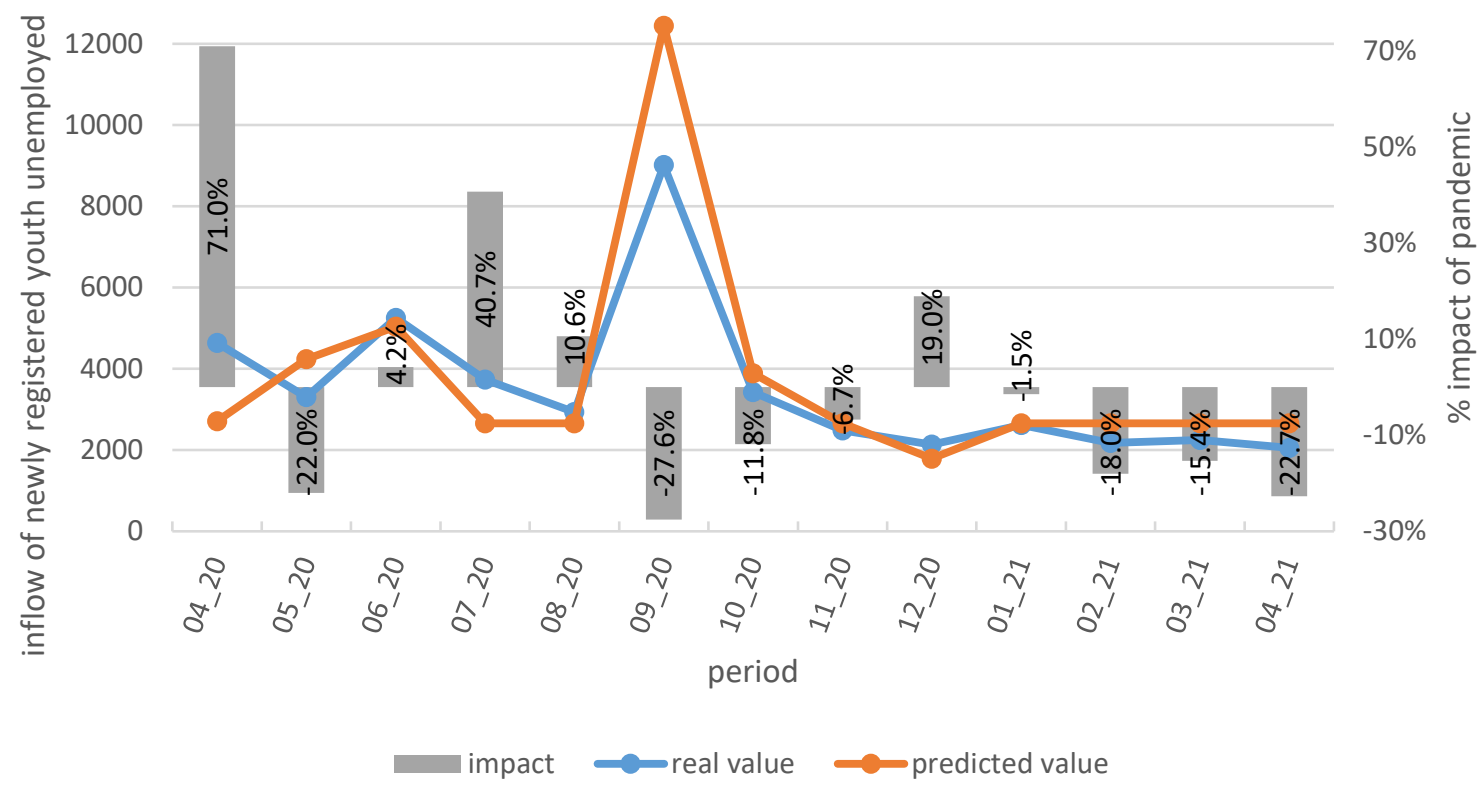

Figure 3: Counterfactual impact evaluation of the pandemic on youth unemployment.

Source: own elaboration.

Figure 3 also shows the monthly percentage increase or decrease in the number of newly registered youth jobseekers compared to the hypothetical counterfactual situation without the pandemic (grey bars). We can note that in April 2020, when the first strict anti-pandemic measures came into force in Slovakia to prevent the spread of the COVID-19 virus, the inflow of new youth jobseekers increased by $71 \%$ compared to the predicted number. It was, in absolute terms, an increase of more than 1,900 new young jobseekers only in that month. It is a significant increase, considering the fact that the numbers are around $2-3$ thousand per month. Another big difference was in July 2020, when the number of new young jobseekers was almost $41 \%$ (above 1,080 people) higher than the counterfactual estimate, and in December 2020 by almost 19\% (approximately 340 people). In addition, however, the number of real new young jobseekers was even lower in some months than the predicted number (May 2020, September
2020 and the last months of the observed period). On average, during the COVID-19 pandemic, the inflow of young unemployed increased by $1.54 \%$ per month (standard deviation $=27.27 \%$, coefficient of variation $=$ $17.72 \%)$.

To compare the extent of the impact of the pandemic, we also presented the results for the other two age categories of new jobseekers, namely 25 - 55 years and 55 and over. In the 25 - 55 age group, the impact of the pandemic appears to be strong. The regression model for the inflow of newly registered jobseekers in this age group is in Table 3 (ANOVA p-value $<0.05$; R-square $=0.828$ ). 
Table 3: Regression model of the inflow of newly registered jobseekers aged 25 - 55

\begin{tabular}{|l|c|c|c|c|c|c|c|}
\hline Variable & $\begin{array}{c}\text { Unstandardized } \\
\text { Coefficients B }\end{array}$ & Std. Error & $\begin{array}{c}\text { Standardi } \\
\text { zed } \\
\text { coefficien } \\
\text { ts Beta }\end{array}$ & $\mathbf{t}$ & Sig. & $\begin{array}{c}\text { Collinearit } \\
\mathbf{y} \\
\text { Tolerance }\end{array}$ & VIF \\
\hline Constant & -115723.54 & 26004.11 & & -4.45 & $<0.05$ & & \\
\hline season=1 & 3090.86 & 440.35 & 0.46 & 7.02 & $<0.05$ & 0.92 & 1.09 \\
\hline $\begin{array}{l}\text { middle } \\
\text { population }\end{array}$ & 0.11 & 0.02 & 0.31 & 4.96 & $<0.05$ & 0.99 & 1.01 \\
\hline season=10 & 1348.75 & 465.10 & 0.19 & 2.90 & $<0.05$ & 0.93 & 1.07 \\
\hline season=12 & -2200.68 & 465.10 & -0.31 & -4.73 & $<0.05$ & 0.93 & 1.07 \\
\hline season=8 & -2189.40 & 465.10 & -0.31 & -4.71 & $<0.05$ & 0.93 & 1.07 \\
\hline season=2 & -1785.02 & 440.35 & -0.27 & -4.05 & $<0.05$ & 0.92 & 1.08 \\
\hline season=3 & -1341.77 & 440.35 & -0.20 & -3.05 & 0.003 & 0.92 & 1.08 \\
\hline
\end{tabular}

Source: own elaboration

Figure 4 shows a comparison of the counterfactual situation - what would have happened in the absence of the pandemic with the real inflow of new jobseekers in this age group during April 2020 - April 2021. In this age group, anti-pandemic government measures manifested themselves immediately at the beginning of the pandemic. As a result, the inflow of newly unemployed in April 2020 increased by $84 \%$, which in absolute terms is 9,651 new jobseekers more than predicted. Also, in all other months of 2020, the impact of the pandemic on unemployment in this age group is significant. In absolute terms, the total for April - December 2020 is almost 287,000 newly unemployed more than the counterfactual estimate. Thus, the impact of the pandemic on this age group is quantified by the evaluation parameter $A T E$ :

$$
\begin{gathered}
A T E_{\text {age } 25-55}=E\left(Y_{1}\right)-E\left(Y_{0}\right) \doteq 12,963-10,915 \\
=2,048 .
\end{gathered}
$$

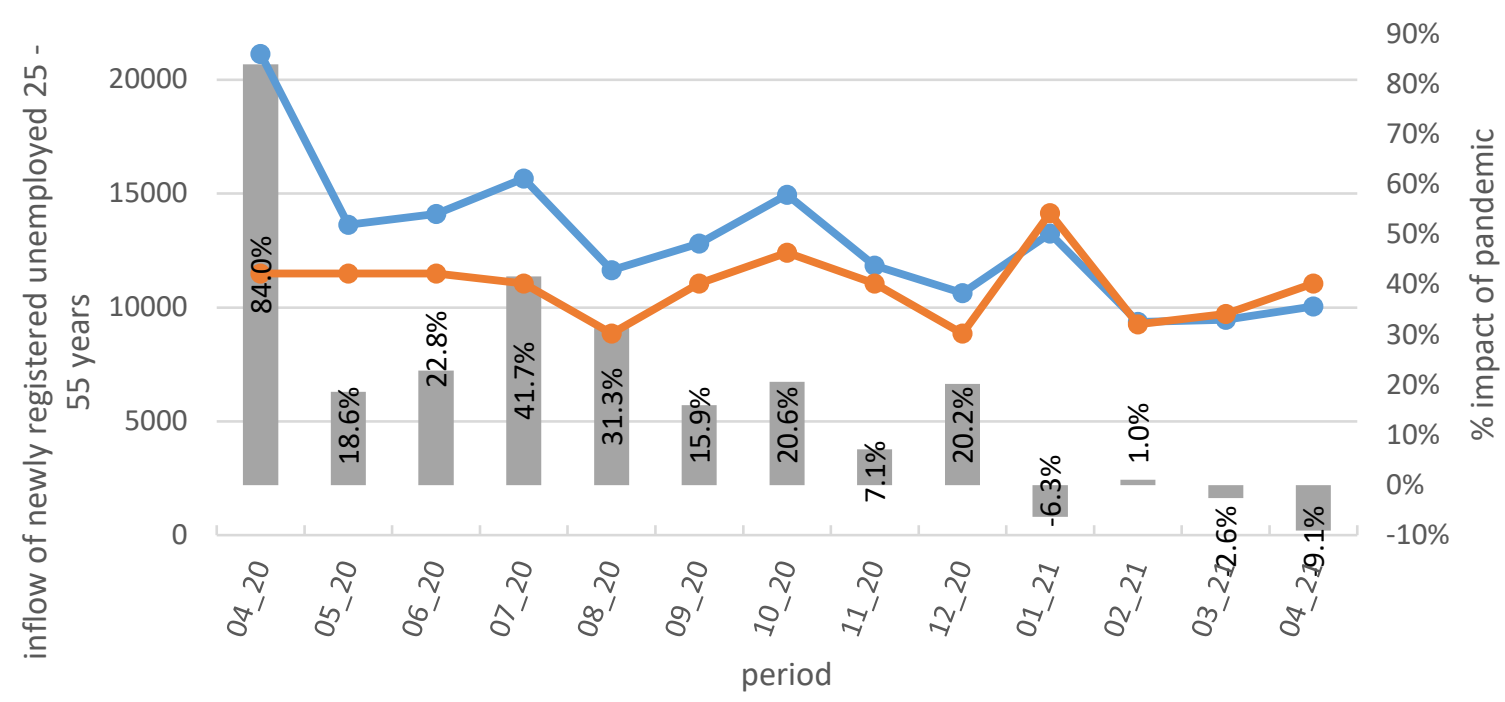

impact $\longrightarrow$ real value $\longrightarrow$ predicted value

Figure 4: Counterfactual impact evaluation of the pandemic on unemployment in the age group 25 55 years.

Source: own elaboration. 
That means 2,048 newly registered jobseekers monthly, more than estimated by counterfactual prediction in the situation without the pandemic. The average percentage difference is $18.87 \%$ (standard deviation $=23.68 \%$, coefficient of variation $=125.45 \%$ ).
Finally, in the group of people aged 55 and over, the impact of the pandemic is the strongest. Table 4 shows the regression model for the inflow of new jobseekers in this age group (ANOVA p-value $<0.05 ;$ R-square $=0.824$ ).

Table 4: Regression model of the inflow of newly registered jobseekers aged 25 - 55

\begin{tabular}{|c|c|c|c|c|c|c|c|}
\hline Variable & $\begin{array}{c}\text { Unstandardized } \\
\text { Coefficients B }\end{array}$ & $\begin{array}{c}\text { Std. } \\
\text { Error }\end{array}$ & $\begin{array}{c}\text { Standardized } \\
\text { Coefficients } \\
\text { Beta }\end{array}$ & $\mathbf{t}$ & Sig. & $\begin{array}{c}\text { Collinearity } \\
\text { Tolerance }\end{array}$ & VIF \\
\hline Constant & -683.9 & 721.07 & & -0.95 & 0.35 & & \\
\hline $\begin{array}{c}\text { older_- } \\
\text { population }\end{array}$ & 0.003 & 0.001 & 0.21 & 3.27 & $<0.05$ & 0.99 & 1 \\
\hline season_1 & 912.84 & 79.17 & 0.75 & 11.53 & $<0.05$ & 0.95 & 1.5 \\
\hline season_7 & 199.41 & 83.93 & 0.15 & 2.38 & 0.02 & 0.96 & 1.5 \\
\hline season_8 & -183.59 & 83.93 & -0.14 & -2.19 & 0.03 & 0.96 & 1.5 \\
\hline season_10 & 311.12 & 83.93 & 0.24 & 3.71 & 0 & 0.96 & 1.5 \\
\hline season_11 & 205.12 & 83.93 & 0.16 & 2.44 & 0.02 & 0.96 & 1.5 \\
\hline
\end{tabular}

Source: own elaboration

The numbers of newly unemployed in this age group are the lowest throughout the observed period. Still, it turned out that the actual development differed most significantly from the predicted counterfactual development in relative terms. The monthly situation is shown in Figure 5.

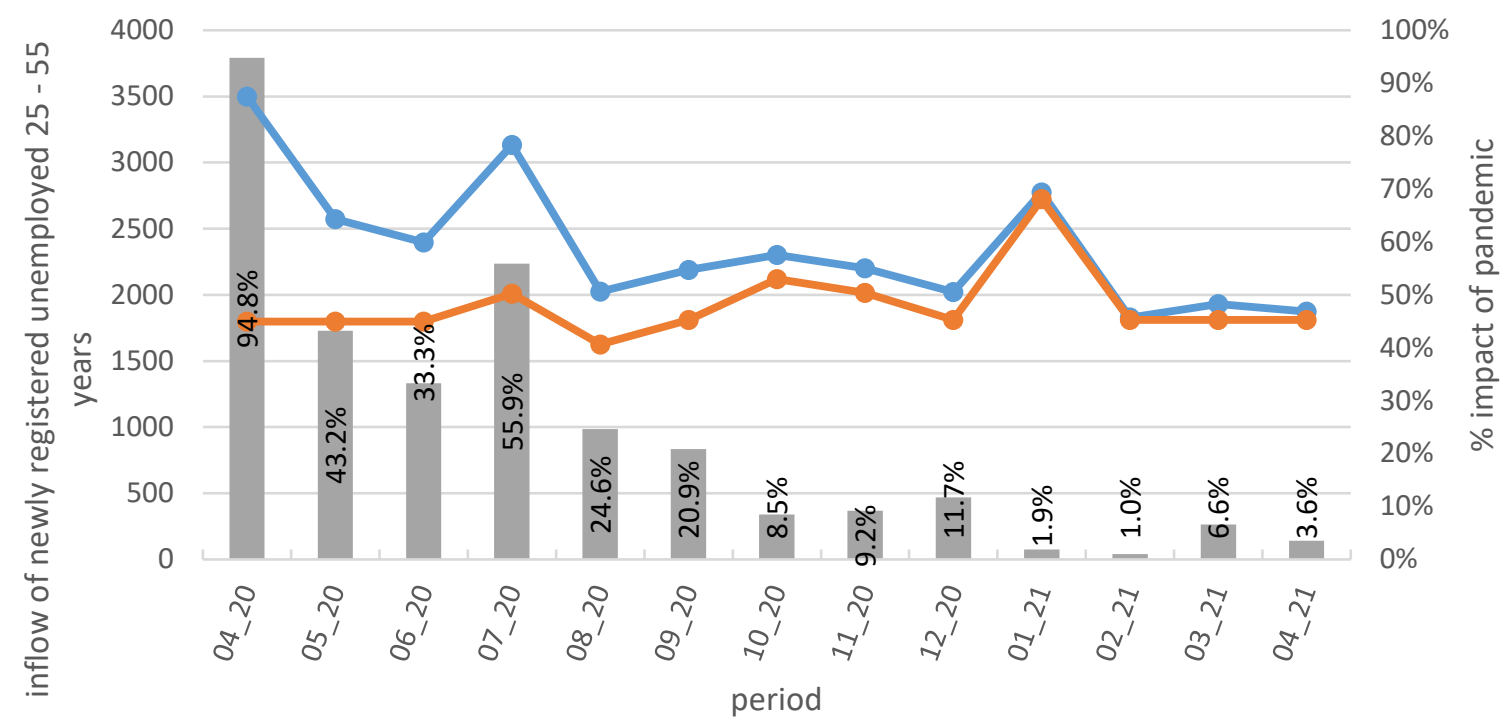

$\%$ impact $\longrightarrow$ real value predicted value

Figure 5: Counterfactual impact evaluation of the pandemic on unemployment in the age group 55 and older.

Source: own elaboration. 
Immediately after introducing anti-pandemic measures in April 2020, the inflow of new jobseekers in this age group increased by almost $95 \%$, which is 1,702 new unemployed more than was predicted in this one month alone. In 2021, the impact of the pandemic is almost disappearing; the difference in the actual number of new jobseekers is slightly higher than predicted. Over the entire pandemic period, the inflow of unemployed in this age group has increased by more than 5,800 people compared to the prediction. The impact of the pandemic, expressed using the ATE evaluation parameter, is:

$$
\begin{aligned}
A T E_{55 \text { and older }}= & E\left(Y_{1}\right)-E\left(Y_{0}\right) \doteq 2,365-1,918 \\
& =447 .
\end{aligned}
$$

That is, on a monthly average, 447 more newly registered jobseekers in this age group than were estimated by the counterfactual prediction. The average monthly percentage difference is $24.24 \%$ ( standard deviation $=26.07 \%$, coefficient of variation $=107.55 \%$ ).

\section{DISCUSSION}

In their studies, some authors have addressed similar issues of quantifying the impact on unemployment in general, or youth unemployment in particular. Churchill (2021) studied the impact of the pandemic on youth employment in Australia compared to the older generation, comparing both genders. The author compared the unemployment rates in 2000 and 2008 with the rates in the year 2020. This research has shown that young people have been significantly affected by the pandemic regarding their unemployment. During the observed period from February to June 2020, mainly young women aged 15 to 19 and 20 to 24 , whose unemployment increased by $3.2 \%$ and $4.21 \%$ respectively, are exposed to the economic impact, while for older women, the unemployment increased by about $1-1.5 \%$ during the period under review. In our study, we analyzed the two age groups altogether, as individuals are registered in the COLSAF SR database in such an age group, but we considered the method used to be a more accurate estimate of the impact of the pandemic. In any case, the increase in the unemployment rate in Slovakia was on average $1.54 \%$, but with a higher variability of 27.27\%. Ranchhod and Daniels
(2021), in their study, analyzed the labor market in South Africa at the beginning of the 2020. The authors of the study stated that in April 2020, many people became unemployed. Among those who had already been unemployed, many people stopped looking for work, both because of antipandemic measures and the impossibility of finding a job. Therefore, young people and their employment were also among the groups impacted by the pandemic. In the study by Djoumessi (2021), the author stated that more than half of companies had a drastic reduction in employees' wages in Cameroon; more than 30\% had a temporary suspension of work, and almost $7.5 \%$ of workers lost their jobs.

Interestingly, the young population in this country was not as affected by the impact of the pandemic as the middle generations during the period under review. We found similar results in our study. The middle and older generation in Slovakia appeared to be more affected by the pandemic, especially during 2020 . The situation in the Canadian labor market in February - April 2020 is analyzed in the study by Lemieux et al. (2020). The authors monitored changes in employment in the age group of $20-64$. Based on the research results, the pandemic's impact is most pronounced on the group of younger workers aged 20 - 29, whose total number of hours worked has decreased by up to $40 \%$, and unemployment has increased by $25 \%$ due to downtime. While in the group of workers aged 40 - 49, the changes in hours worked and unemployment were the smallest, where employment fell by $12 \%$. In a study by von Wachter (2020), the author focused on analyzing the effects of the pandemic on the US labor market. The author examined mainly job losses during 2020 and their long-term economic impacts, and also focused on young people entering the labor market for the first time as new school leavers. In the article, the author also proposed policy measures to mitigate the effects of the pandemic. Such an approach could be an inspiration for the possible future direction of our study. In the continuation of this study, we want to obtain more accurate results by updating the data and then using cost-benefit analysis to evaluate the effects of the pandemic on youth unemployment and other age groups from an economic point of view. This evaluation could then be used to adapt the conditions for 
implementing the active labor market policy interventions that are currently in practice or to propose new such instruments to mitigate the effects of the pandemic.

\section{CONCLUSION AND RECOMMENDATION}

In this study, we focused on assessing the effects of the COVID-19 pandemic on youth unemployment, measured by the monthly inflow of new jobseekers registered in the database of jobseekers in the COLSAF SR. Unemployment is currently one of the biggest problems in our society. Young people in the labor market are seen especially as a very specific group. Finding a job is often very difficult for young people, mainly due to having minimal or no experience. When the Slovak government was forced to take shut-down measures to prevent the spread of the disease, the problem of unemployment worsened. For this reason, we carried out an impact evaluation using a counterfactual approach to before-after comparison by modelling the time series of the development of this variable and then using this model to predict "what would have happened in the absence of the pandemic," and comparing this prediction with the real situation. Such an approach to evaluation yields accurate results.

To summarize, in the group of young people under 25, the COVID-19 pandemic had a significant impact in some months, especially at the beginning, after introducing strict measures in Slovakia. On average, the number of new jobseekers in this age group increased by 207 per month. For comparison, we also evaluated the situation in the groups of jobseekers aged $25-55$ years and 55 and older. In the group of $25-55$ years, the pandemic manifested itself mainly during 2020, the strongest again at its beginning in Slovakia. On average, in this age group, the inflow of new jobseekers increased by 2,049 people per month compared to the prediction. Finally, in the age group 55 and over, the pandemic was strongest in relative terms, mainly at the beginning, when the inflow of new jobseekers almost doubled. On average, the number of new jobseekers per month increased by 447 people compared to the prediction. In percentages, the increase in newly unemployed people was $5.8 \%$ in the group of young people under 25 years, $18.8 \%$ in the age group $25-55$ years and $23.3 \%$ in the age group 55 and over. These percentages are calculated as an increase in the number of newly unemployed compared to the counterfactual situation in the absence of the pandemic, predicted using the created regression models. It is useful to quantify the effects of the pandemic in this way as well because, on the one hand, the numbers of newly unemployed have clearly increased compared to the situation if the pandemic had not come, but if we want to compare the impact, it is necessary to express them relatively, because the inflow of newly registered jobseekers is naturally different in individual age groups even under normal circumstances. The following result can therefore be concluded. According to relative numbers, the impact of the pandemic was strongest on the oldest age group over 55 , the middle age group was affected in the middle and the youngest age group the least. These results can be used directly in practice when setting the conditions for the eligibility of active labor market policy measures to increase the employment of people affected by the pandemic. Based on the results of this study, these intervention tools need to be targeted mostly at the older age group of the population. Based on the amount of impact and the number of newly unemployed individuals that have increased as an impact of a pandemic, it is also possible to set the amount of allocation of funds needed for the operation of these instruments in practice.

In addition, however, we can summarize for all age groups that the situation is already better in 2021. The impact of the pandemic on unemployment is not so strong; for young people, the number of new jobseekers is even lower than predicted, and in the other two age groups, the number of new jobseekers is higher than predicted. Still, this is no longer as big a difference as in 2020. Here, however, we must admit some limitations of this study. The prediction for 2021 is not entirely accurate due to using the population number for a given age category current for 2020 because newer data have not been published when this study was conducted. We consider this fact a weakness of the evaluation, but we believe that the difference in results will not be huge. In addition, we consider the limitation of the study the fact that these population numbers are published and used in the study on a semi-annual basis, while 
the inflow of new jobseekers is modelled monthly.

Nevertheless, we assume that the differences in results would not be very large, as the population does not differ diametrically from month to month. Of course, obtaining such data would refine the results of this study. We can also consider a limit of the study the fact that the evaluation was comprehensive and focused only on the whole of Slovakia, while in individual regions the unemployment rates reached different levels. Focusing on these details could be another direction of this study, in which we intend to analyze the impact of the COVID-19 pandemic not only on different age groups, but also on individual regions of Slovakia, groups with different levels of highest educational attainment, for both genders, and of course, interactions between these population characteristics.

\section{ACKNOWLEDGEMENT}

The authors are thankful to the Internal Grant Agency of University No. 1/KE/2020: "Application of counterfactual methods of impact evaluation on selected intervention measures" for financial support to carry out this research.

\section{REFERENCES}

Almeida, F., \& Santos, J. D. (2020). The effects of COVID-19 on job security and unemployment in Portugal. International Journal of Sociology and Social Policy, 40(9/10), 995-1003. https://doi.org/10.1108/IJSSP-07-2020-0291

Al-Youbi, A. O., Al-Hayani, A., Rizwan, A., \& Choudhry, H. (2020). Implications of COVID19 on the Labor Market of Saudi Arabia: The Role of Universities for a Sustainable Workforce. Sustainability, 12(17), 7090. https://doi.org/10.3390/su12177090

Blustein, D. L., Duffy, R., Ferreira, J. A., CohenScali, V., Cinamon, R. G., \& Allan, B. A. (2020). Unemployment in the time of COVID-19: A research agenda. Journal of Vocational Behavior, 119, 103436. https://doi.org/10.1016/j.jvb.2020.103436

Danielova, K., \& Lauko, V. (2014). Impact of the Economic Crisis on the Gender Wage
Difference and Unemployment in Slovakia. Geographical Information, 18(1), 24-33. https://doi.org/10.17846/GI.2014.18.1.24-33

Djoumessi, Y. F. (2021). The adverse impact of the Covid-19 pandemic on the labor market in Cameroon. African Development Review, 1-14. https://doi.org/10.1111/14678268.12508

Dvorak, M., Rovny, P., Grebennikova, V., \& Faminskaya, M. (2020). Economic impacts of Covid-19 on the labor market and human capital. Terra Economicus, 18(4), 78-96. https://doi.org/10.18522/2073-6606-202018-4-78-96

Dvoulety, O., \& Lukes, M. (2016). Review of Empirical Studies on Self-Employment out of Unemployment: Do Self-Employment Policies Make a Positive Impact? International Review of Entrepreneurship, 14(3), 361-376.

Fialova, K., \& Mysikova, M. (2021). Minimum Wage and Youth Employment in Regions of the Visegrád Countries. Eastern European Economics, 59(1), 82-102. https://doi.org/10.1080/00128775.2020.181 6474

Flek, V., Hala, M., \& Mysikova, M. (2018). Unemployment and age segmentation of the labor market. Politicka Ekonomie, 666), 709-731. https://doi.org/10.18267/j.polek.1227

Frondel, M., \& Schmidt, C. M. (2005). Evaluating environmental programs: The perspective of modern evaluation research. Ecological Economics, 55(4), 515-526. https://doi.org/10.1016/j.ecolecon.2004.12.0 13

Galea, S., \& Abdalla, S. M. (2020). COVID-19 Pandemic, Unemployment, and Civil Unrest: Underlying Deep Racial and Socioeconomic Divides. JAMA, 324(3), 227-228. https://doi.org/10.1001/jama.2020.11132

Graham, J., \& Ozbilgin, M. (2021). Age, Industry, and Unemployment Risk During a Pandemic Lockdown (SSRN Scholarly Paper ID 3772576). Social Science Research Network. https://doi.org/10.2139/ssrn.3772576

Greganova, R., \& Pietrikova, M. (2017). Changes in Development of Regional Unemployment and Foreign Direct Investment in Conditions in Slovakia. Proceedings of the 20th International Colloquium on Regional 
Sciences, 147-154.

https://doi.org/10.5817/CZ.MUNI.P2108587-2017-18

Churchill, B. (2021). COVID-19 and the immediate impact on young people and employment in Australia: A gendered analysis. Gender, Work \& Organisation, 28(2), 783-794.

https://doi.org/10.1111/gwao.12563

Ibn-Mohammed, T., Mustapha, K. B., Godsell, J., Adamu, Z., Babatunde, K. A., Akintade, D. D., Acquaye, A., Fujii, H., Ndiaye, M. M., Yamoah, F. A., \& Koh, S. C. L. (2021). A critical analysis of the impacts of COVID-19 on the global economy and ecosystems and opportunities for circular economy strategies. Resources, Conservation and Recycling, 164, 105169. https://doi.org/10.1016/j.resconrec.2020.10 5169

ILO-OECD. (2020). The impact of the COVID-19 pandemic on jobs and incomes in $G 20$ economies. International Labour Oraganization.

Ismayilzade, A. A., Guliyeva, S., Teymurova, V., Azizova, R., \& Alishova, C. (2021). The impact of Covid-19 on the quality of human capital for the economic development of Azerbaijan. Journal of Eastern European and Central Asian Research (JEECAR), 8(1), 2639. https://doi.org/10.15549/jeecar.v8i1.639

Kopacek, M., \& Horackova, L. (2018). Young people and the labor market: A case study of regions in the Visegrad countries.

Proceedings of the 20th International Colloquium on Regional Sciences, 78-85. https://doi.org/10.5817/CZ.MUNI.P2108970-2018-9

Kruppe, T., \& Lang, J. (2018). Labour market effects of retraining for the unemployed: The role of occupations. Applied Economics, 50(14), 1578-1600.

https://doi.org/10.1080/00036846.2017.136 8992

Lemieux, T., Milligan, K., Schirle, T., \& Skuterud, M. (2020). Initial impacts of the COVID-19 pandemic on the Canadian labour market. Canadian Public Policy, 46(S1), S55-S65. https://doi.org/10.3138/cpp.2020-049

Marinescu, I., Skandalis, D., \& Zhao, D. (2021). The Impact of the Federal Pandemic Unemployment Compensation on Job Search and Vacancy Creation (Working
Paper Č. 28567; Working Paper Series). National Bureau of Economic Research. https://doi.org/10.3386/w28567

McGann, M., Murphy, M. P., \& Whelan, N. (2020). Workfare redux? Pandemic unemployment, labour activation and the lessons of post-crisis welfare reform in Ireland. International Journal of Sociology and Social Policy, 40(9/10), 963-978. https://doi.org/10.1108/IJSSP-07-2020-0343

Milani, F. (2021). COVID-19 outbreak, social response, and early economic effects: A global VAR analysis of cross-country interdependencies. Journal of Population Economics, 34(1), 223-252. https://doi.org/10.1007/s00148-020-007924

Nemec, J. (2020). Government transition in the time of the COVID-19 crisis: Slovak case. International Journal of Public Leadership, 171), 7-12. https://doi.org/10.1108/IJPL-052020-0040

OECD. (2020a). UnemploymentUnemployment rate by age group-OECD Data. TheOECD. http://data.oecd.org/unemp/unemployment -rate-by-age-group.htm

OECD. (2020b). Unemployment-Youth unemployment rate-OECD Data. TheOECD. http://data.oecd.org/unemp/youthunemployment-rate.htm

OECD. (2021). Youth unemployment rate doi: 10.1787/c3634df7-en

O’Keeffe, P., Johnson, B., \& Daley, K. (2021). Continuing the precedent: Financially disadvantaging young people in "unprecedented" COVID-19 times. Australian Journal of Social Issues, forthcoming article. https://doi.org/10.1002/ajs4.152

Pelucha, M., Kveton, V., \& Potluka, O. (2019). Using mixed method approach in measuring effects of training in firms: Case study of the European Social Fund support. Evaluation and Program Planning, 73, 146-155. https://doi.org/10.1016/j.evalprogplan.2018. 12.008

Potluka, O., Bruha, J., Spacek, M., \& Vrbova, L. (2016). Counterfactual Impact Evaluation on EU Cohesion Policy Interventions in Training in Companies. Ekonomicky Casopis, 64(6), 575-595. 
Privara, A. (2020). Labour market efficiency and emigration in Slovakia and EU neighbouring countries. Economic Research-Ekonomska Istraživanja, forthcoming article, 1-21. https://doi.org/10.1080/1331677X.2020.185 8131

Radulescu, C. V., Ladaru, G.-R., Burlacu, S., Constantin, F., Ioanăș, C., \& Petre, I. L. (2021). Impact of the COVID-19 Pandemic on the Romanian Labor Market. Sustainability, 13(1), 271. https://doi.org/10.3390/su13010271

Ranchhod, V., \& Daniels, R. C. (2021). Labour market dynamics in South Africa at the onset of the COVID-19 pandemic. South African Journal of Economics, 89(1), 44-62. https://doi.org/10.1111/saje.12283

Song, L., \& Zhou, Y. (2020). The COVID-19 Pandemic and Its Impact on the Global Economy: What Does It Take to Turn Crisis into Opportunity? China \& World Economy, 28(4), 1-25 https://doi.org/10.1111/cwe.12349

Statistical office of the Slovak Republic. (2021). DATAcube. http://datacube.statistics.sk/

Stefanik, M. (2014). Estimating treatment effects of a training programme in Slovakia using propensity score matching. Ekonomicky Casopis, 62(6), 631-645.

Stefanik, M., Karasova, K., \& Studena, I. (2020). Can supporting workplace insertions of unemployed recent graduates improve their long-term employability? Empirica, 472), 245-265. https://doi.org/10.1007/s10663018-9413-y

Svabova, L., \& Kramarova, K. (2021). An analysis of participation factors and effects of the active labour market measure Graduate practice in Slovakia - Counterfactual approach. Evaluation and Program Planning, 86, 101917.

https://doi.org/10.1016/j.evalprogplan.2021. 101917

Svabova, L., Metzker, Z., \& Pisula, T. (2020). Development of Unemployment in Slovakia in the Context of the COVID-19 Pandemic. Ekonomicko-manazerske spektrum, 14(2), 114-123. https://doi.org/10.26552/ems.2020.2.114123

Trivellato, U. (2011). Fifteen years of labour market regulations and policies in Italy:
What have we learned from their evaluation? Statistica, 71(2), 167-187. https://doi.org/10.6092/issn.19732201/3610

von Wachter, T. (2020). Lost Generations: LongTerm Effects of the COVID-19 Crisis on Job Losers and Labour Market Entrants, and Options for Policy. Fiscal Studies, 41(3), 549-590. https://doi.org/10.1111/14755890.12247

\section{ABOUT THE AUTHORS}

Lucia Svabova, email: lucia.svabova@fpedas.uniza.sk

Dr. Lucia Svabova is an Associate Professor at the Department of Economics, Faculty of Operation and Economics of Transport and Communications, University of Zilina, Slovak Republic. Her research interests are in statistics, econometrics, multivariate statistical methods, counterfactual impact evaluation, and financial derivatives.

Barbora Gabrikova is a student at the Department of Economics, Faculty of Operation and Economics of Transport and Communications, University of Zilina, Slovak Republic. She is a potential doctoral student. Within the doctoral study, she would like to deal with the application of counterfactual methods of impact assessment to evaluate active labour market policy interventions aimed at the target group of companies. 